\title{
Evaluation of the Relationship between Epiphytic Diatoms and Water Quality Parameters in the Büyükçekmece Reservoir
}

\author{
Tumer Orhun Aykut $^{1}{ }^{\mathbb{D}}$, Neslihan Balkis-Ozdelice ${ }^{2}$ (D) Turgay Durmus $^{2}$ (D), \\ Cuneyt Nadir Solak ${ }^{3}$
}

IIstanbul University, Institute of Science, Istanbul, Turkey

${ }^{2}$ Istanbul University, Faculty of Science, Department of Biology, Istanbul, Turkey

${ }^{3}$ Kütahya Dumlupınar University, Faculty of Arts and Sciences, Kütahya, Turkey

ORCID IDs of the authors: T.O.A. 0000-0002-0791-8127; N.B.O. 0000-0001-8030-7480; T.D. 0000-0002-8242-1823; C.N.S. 0000-0003-2334-4271

Please cite this article as: Aykut TO, Balkis-Ozdelice N, Durmus T, Solak CN. Evaluation of the Relationship between Epiphytic Diatoms and Water Quality Parameters in the Büyükçekmece Reservoir. Eur J Biol 2021; 80(1): 54-68. DOI: 10.26650/EurJBiol.2021.932485

\section{ABSTRACT}

Objective: In this study carried out in Büyükçekmece Reservoir, the composition, distribution, seasonal changes of epiphytic diatoms that live on the surfaces of plants, and the effects of environmental parameters on these organisms were investigated, and it was aimed to reveal the water quality of the reservoir.

Materials and Methods: In order to determine the seasonal changes of epiphytic diatom species in Büyükçekmece Reservoir, water and material samples were collected from five stations in 2019. In the study, water temperature, salinity, conductivity, dissolved oxygen, and $\mathrm{pH}$ values, which are among the basic ecological variables, were measured. Epiphytic diatom samples were obtained from Phragmites sp. species. Also, Spearman's rank correlation, Shannon-Weaver diversity index, Cluster (Bray-Curtis and Euclidean Distance), and ordination analysis (DCA and CCA) were applied in the study.

Results: 66 epiphytic diatom species were identified in this study, and 36 of these species are new records for the reservoir. Most epiphytic diatom species were obtained in August, and the lowest number was obtained in November. According to the $\mathrm{pH}$ values, it was determined that the reservoir is alkaline. In addition, it was determined that the main factors affecting the distribution of epiphytic diatom species in the reservoir are temperature and conductivity, and it was revealed that ecological variables affect species distribution.

Conclusion: According to conductivity and DO values, it was determined that the reservoir was of very good and of good quality, and in terms of DO values, the reservoir was mainly oligotrophic. However, station 5 was mesotrophic during the August sampling period, station 4 was mesotrophic, and station 5 was eutrophic in November. Also, Büyükçekmece Reservoir was found in poor and moderate status according to $H^{\prime}$ classification.

Keywords: Epiphytic diatom, Bacillariophyceae, Correlation, Water quality, Istanbul, Turkey

\section{INTRODUCTION}

Diatoms (Bacillariophyceae) are among the unicellular, microscopic groups of algae with high distribution in freshwaters. Their existence on Earth, dating back 185 million years ago, has been proven by the fossil records
(1). Diatoms are responsible for almost $20-25 \%$ of the oxygen produced on Earth in aquatic ecosystems (2). Diatoms constitute the vast majority of benthic algae species in freshwater and seas $(3,4)$, and they are distributed in almost all habitats. Due to their high tolerance range against environmental factors, they 
spread in a wide variety of aquatic environments (5-7). In their environment, they play an important role in the food chain for other aquatic organisms (8). By taking part in the carbon cycle through the photosynthesis process they perform, these organisms present in the photic zone play a key role in the elimination of atmospheric greenhouse gases that significantly contribute to global warming (9). They are used in biological monitoring studies because they respond to environmental parameters and the changes of these parameters faster than other living things. The presence of diatoms in all kinds of aquatic ecosystems, their ability to reach a high number of species even in small areas, including polluted and clean waters, and easy sampling are why they are preferred for comparing aquatic ecosystems with each other.

In recent years, the growths in industrialization, the excessive proliferation of the human population, and human insensitivity to the ecosystem have brought many environmental problems. It is worrying for humanity that freshwater reserves necessary for life are rapidly depleted or have become unusable. Protection of surface water resources and monitoring water pollution are among the priority points of many countries. For this reason, the use of biological organisms has increased in recent years in monitoring water pollution situations. Many countries have defined the biological quality steps by continuously following their current water potentials and have developed a national water quality system to monitor these resources in certain periods. While European Union member countries carry out these studies within the scope of the EU Water Framework Directive (WFD) (10), in Turkey, according to the Water Pollution Control Regulation (11) and the Surface Water Quality Control Regulation (12), determinations can be made about the water quality status of the resources. Although the commonly used parameters are various basic ecological variables such as water temperature, $\mathrm{pH}$, dissolved oxygen, and nutrients, the excessive increase or decrease of some biological groups depending on these variables are observed. In particular, species composition and the abundance status of diatoms change depending on these variables and are used as an important indicator in determining the trophic status of lakes (13-16).

When the studies carried out in Büyükçekmece Reservoir are evaluated, it has been seen that the studies include all algae groups which are generally living in benthic and pelagic plankton (17-24). Also, studies on benthic algae have also been carried out, and it has been revealed that the diatoms are dominant organisms compared to the other groups in terms of the number of species in all of the studies. Among these studies, Temel (17) conducted a study on epipelic algae in the reservoir and defined the benthic flora of the lake as very poor in terms of species and abundance. The same researcher studied epiphytic and epilithic algae in another study and reported that 43 diatom species were encountered in the epiphytic habitat in the Büyükçekmece Reservoir (18). In addition to these studies carried out in the reservoir, the importance of the water catchment areas is another reason for this study. Lakes, one of the most important freshwater reserves, are important natural areas with many features such as their biological life and their roles in fishing, recreation, tourism, and the hydrological cycle. Since the water catchment basins of the reservoirs are wider than natural lakes, they are more affected by the pollution in the basin. Therefore, it is necessary to carry out monitoring studies, especially in areas where drinking water is supplied (25). In this context, in this study carried out in Büyükçekmece Reservoir, the composition, distribution, seasonal changes of epiphytic diatoms that survive on plants, and the effects of environmental parameters on these organisms were investigated, and it was aimed to reveal the water quality of the reservoir.

\section{MATERIALS AND METHODS}

\section{Study Area}

While Büyükçekmece Reservoir was one of the coastal lagoons of the Sea of Marmara until 1989, it was disconnected from the sea with an earth-filled embankment and took its current form (26). The reservoir, which is one of the drinking water resources of Istanbul today, is located between the Büyükçekmece, Çatalca, and Esenyurt districts on the European continent of Istanbul. The surface area of this reservoir, which is $2 \mathrm{~km}$ wide and $7 \mathrm{~km}$ long, is $43 \mathrm{~km}^{2} .400,000 \mathrm{~m}^{3}$ of drinking water is obtained per day from the reservoir, which has a maximum water accumulation volume of approximately $149 \times 10^{6} \mathrm{~m}^{3}(27)$.

\section{Sampling and Analysis of Biotic and Abiotic Variables}

In order to determine the seasonal changes of epiphytic diatom species in the Büyükçekmece Reservoir, water and material samples were collected from five stations in 2019 (February, May, August and November) (Figure 1). The main ecological variables of the environment; water temperature, salinity, conductivity, dissolved oxygen, (DO) and $\mathrm{pH}$ values; were measured during the field studies with the YSI-556 model multiprobe.

Diatom samples were obtained by taking $10 \mathrm{~cm}$ long sections from the part of the Phragmites sp. species within the water and $30 \mathrm{~cm}$ below the water surface. In November, it was observed that the water level in the reservoir decreased by up to $40 \%$ (28). In this season, since Phragmites sp. was not found within the water in stations except for station 2, no epiphytic diatom sampling was performed at other stations. The sections taken from the Phragmites sp. species were repeated as three replications for each station. These sections, which were taken into plastic containers with $100 \mathrm{ml}$ of distilled water, were shaken moderately to mix the diatom species with the water, and $4 \%$ formaldehyde (buffered with borax) was added to ensure fixation (29). The samples brought to the laboratory immediately after the field study were kept at room temperature.

\section{Pre-Treatment of Diatom Samples, Preparations of Perma- nent Slides and Identification}

Diatom frustules were burned and permanent slides prepared according to Hendey (30) and Battarbee et al. (31). Accordingly, in order to eliminate the organic material in the cells, the samples were first kept in a $10 \%$ hydrochloric acid $(\mathrm{HCl})$ solution overnight and then washed with distilled water. Then, hydrogen peroxide $\left(\mathrm{H}_{2} \mathrm{O}_{2}\right)$ was added to the samples on a hotplate, 


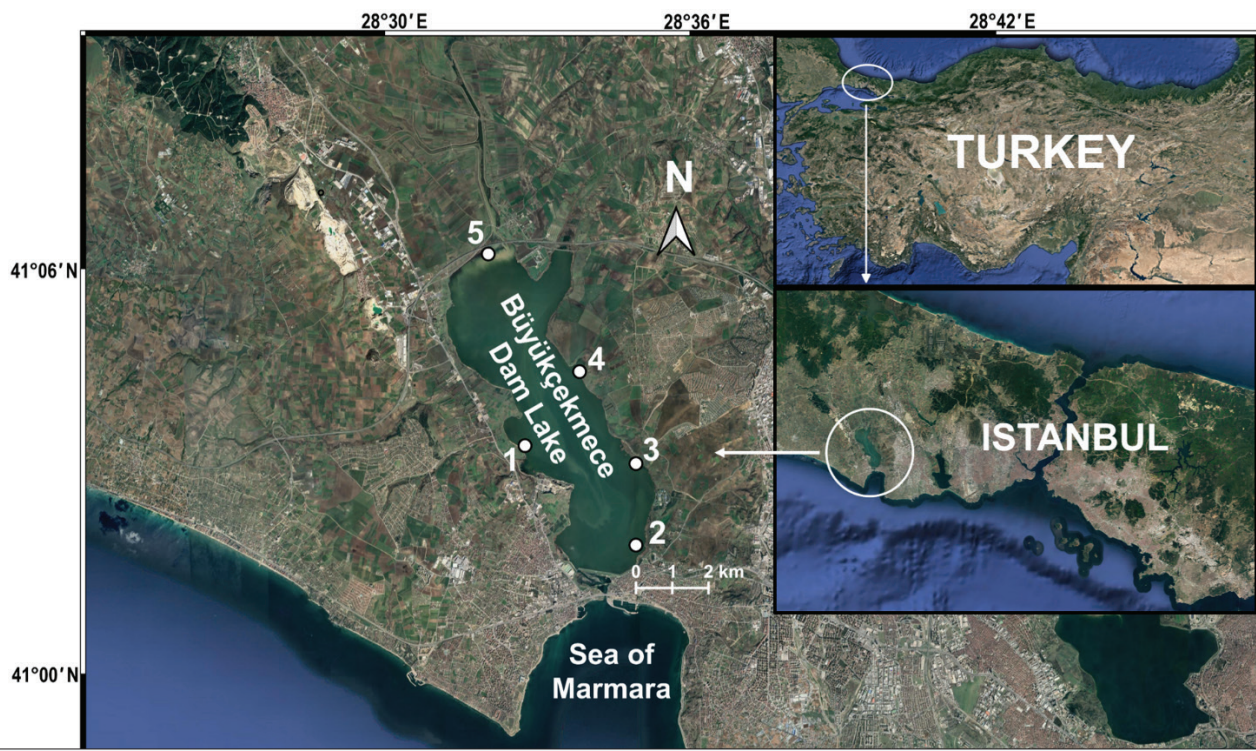

Figure 1. Sampling area and location of stations in the Büyükçekmece Reservoir.

the samples were boiled at $150^{\circ} \mathrm{C}$ for about 5 hours, and their $\mathrm{SiO}_{2}$-containing skeletons were exposed. Naphrax was used in the preparation of permanent slides, and the prepared slides were examined under an Olympus BX51 light microscope at $\times 1000$ magnification. In the identification of the species, Hustedt (32), Patrick and Reimer (33,34), Round et al. (2), and Krammer and Lange-Bertalot (35-38) were used. For each sample from the permanent slides prepared for counting, $300 \mathrm{di}-$ atom frustules were counted randomly under the microscope, and the relative abundance of the species was computed as a percentage.

\section{Statistical Analysis of the Biotic and Abiotic Variables}

Spearman's rank correlation was used in determining the relationship between biotic and abiotic variables (39), Shannon-Weaver diversity index (40) was used in determining the species diversity of stations, and Bray-Curtis similarity analysis was used in determining the similarity of stations according to epiphytic diatom species and individual numbers. Euclidean Distance was used in determining the similarity of stations in terms of ecological variables (41). Before clustering analysis, Bray-Curtis $(\log x+1)$ and Euclidean Distance (Normalisation) data were transformed. From statistical analysis, Spearman's rank correlation was analyzed in the SPSS v.25 package program, while Shannon-Weaver diversity index, Bray-Curtis similarity analysis, and Euclidean Distance were analyzed in the Primer v.6 programs.

Ordination analysis was carried out to reveal the relationship between environmental variables and the relative abundance data of the species. While the method was preferred, firstly, the detrended corresponding analysis (DCA) stated by Lepš and Šmilauer (42) was employed by means of the PC-ORD 6.0 program (43). As the longest gradient was obtained as 4.002 (Axis 1 , Eigenvalue: 0.81737 ) as a result of DCA analysis, the direct gra- dient analysis canonical correspondence analysis (CCA) was preferred for ordination analysis. The first two CCA axes explained a total of $37.9 \%$ of the cumulative variance in species data, and the correlation between the response variable (epiphytic diatoms) and the predictive variables (ecological parameters) was determined as 93.5\%. Environmental variables used in CCA were tested in the SPSS 25.0 program with the Monte Carlo test (with 499 permutations) $(p<0.05)$. The abundance data of diatoms were analyzed by including all sampling periods and species with an observation frequency of "> 5\%" at stations (42), and the CCA ordination diagram was drawn in the PAST 4.0 program (44). In addition, according to the Surface Water Quality Control Regulation (12), the water quality classes and trophic status of the reservoir were revealed. Also, the ecological status of the reservoir has been classified according to Molvær et al. (45), and this classification was based on $H^{\prime}$ values. In this classification, they have been classified into 5 ecological groups as follows: "High status" > 3.8; "Good status" 3.0-3.8; "Moderate status" 1.9-3.0; "Poor status" 0.9-1.9; "Bad status" < 0.9 .

\section{RESULTS}

\section{Ecological Variables}

Results of ecological variables recorded at five stations in Büyükçekmece Reservoir are given in Figure 2. In the measurements performed in the reservoir, it was recorded that the water temperature was between $5.01-26.65^{\circ} \mathrm{C}$. The lowest water temperature was measured at station 3 in the February sampling, and the highest water temperature was measured at station 4 in the August sampling. The values measured in the February sampling are much lower than in the other sampling periods. The highest water temperature in this period was determined as $5.64^{\circ} \mathrm{C}$. During the sampling periods, the highest water temperature variation between stations was observed in the May sampling. Considering the salinity values of the lake during the 

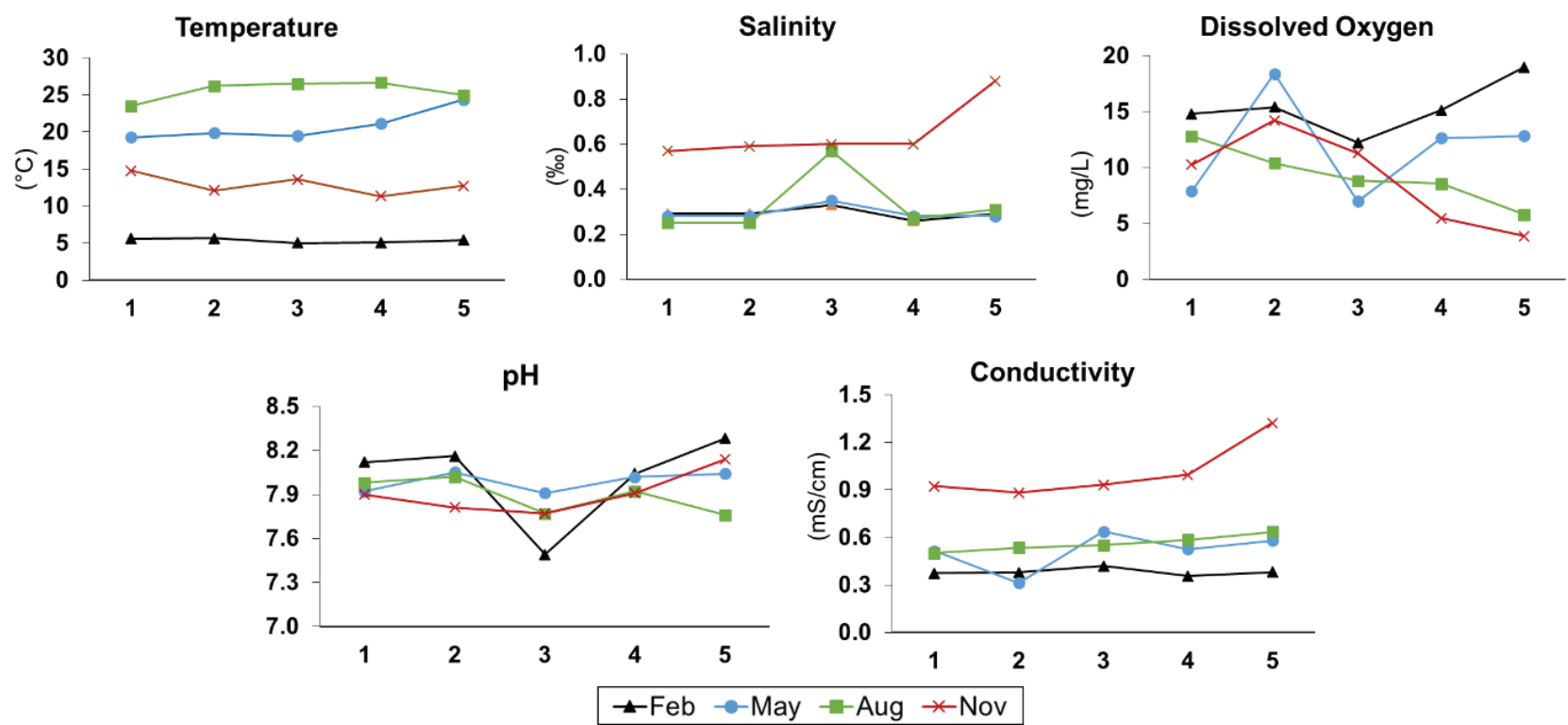

Figure 2. Changes of ecological variables in the Büyükçekmece Reservoir.

year, it was observed that it was below $1 \%$ in all sampling periods and varied between $0.25-0.88 \%$. The lowest value was measured from stations 1 and 2 in the August period, and the highest value was measured from station number 3 in November. During the study, it was observed that the salinity rate of the reservoir was higher in the November sampling, which is the period when the occupancy rate of the reservoir is the lowest, compared to other periods. Dissolved oxygen (DO) values were recorded between 3.87 and $18.96 \mathrm{mg} / \mathrm{L}$. The lowest DO value was measured from station 5 in the November sampling, and the highest value was measured from station 5 in the February sampling.

Conductivity in water was measured as $0.312-1.322 \mathrm{mS} / \mathrm{cm}$ between sampling periods. The lowest conductivity was recorded at station 2 in the May sampling, and the highest was recorded at station 5 in the November sampling. The highest conductivity difference between the stations was obtained in the November sampling. As the $\mathrm{pH}$ values in the reservoir varied between 7.49 and 8.28, it was determined that the reservoir is of alkaline characteristics. The highest (St.5) and lowest (St.3) pH values were measured in the February sampling, and the highest $\mathrm{pH}$ difference between stations was observed in this period.

\section{Epiphytic Diatoms Composition and Abundance}

In this seasonal study conducted in Büyükçekmece Reservoir, 66 epiphytic diatom species were identified, 5 of which were genus level (Figure 3-5). In the study, one (1.5\%) species from centric diatom and 65 (98.5\%) species from pennate diatoms were obtained (Table 1). 36 of the identified species are new records for the reservoir, and the genera Eunotia, Geissleria, Hippodonta, and Tabularia were reported for the first time with this study (Table 1). Most species in the study belonged to Navicula (8 species), followed by Gomphonema (7 species) and
Cymbella (6 species). While the highest number of epiphytic diatom species was obtained in August (43 species) and May (38 species), fewer species numbers were obtained in February (28 species) and November (25 species).

When the number of species obtained at stations was evaluated, the highest number of species was obtained from station 5 (18 species), and the lowest number of species was obtained from station 3 (5 species) in the February sampling. During this sampling period, Fragilaria vaucheriae, Fragilaria sp.2, and Gomphonella olivacea were found in all stations (100\%). When evaluated in terms of relative abundance (Figure 6a), it was determined that $G$. olivacea was dominant in all stations (>49\%) and reached the highest abundance (74\%) at station 1 . In the study, Fragilaria sp.1, Gomphonema sp., Navicula capitatoradiata, Nitzschia intermedia, and Tabularia fasciculata were observed only in this period, and their relative abundance at the stations where they were observed remained below $2 \%$. During this period, a total of 8 cells were found at station 3 , and the targeted 300 cells in terms of relative abundance could not be reached. Among the obtained cells, G. olivacea (50\%) was found to be dominant as in other stations.

In the May sampling, the highest number of species was obtained from station 4 (21 species) and the least number of species from station 2 (12 species). During this period, Achnanthidium sp., Cymbella affinis, Encyonopsis minuta, Fragilaria perminuta, and Gomphonema pumilum were recorded from all stations and in terms of relative abundance (Figure 6b). Cymbella lange-bertalotii (34\%) at station 1, C. affinis (56\%) at station 2, Achnanthidium sp. (40\%) at station 3, Encyonema auerswaldii at station $4(22 \%)$, and G. pumilum (29\%) at station 5 were observed to be dominant. Eunotia bilunaris, Geissleria decussis, Hippodonta hungarica, Navicula novaesiberica, and Tryblionella 


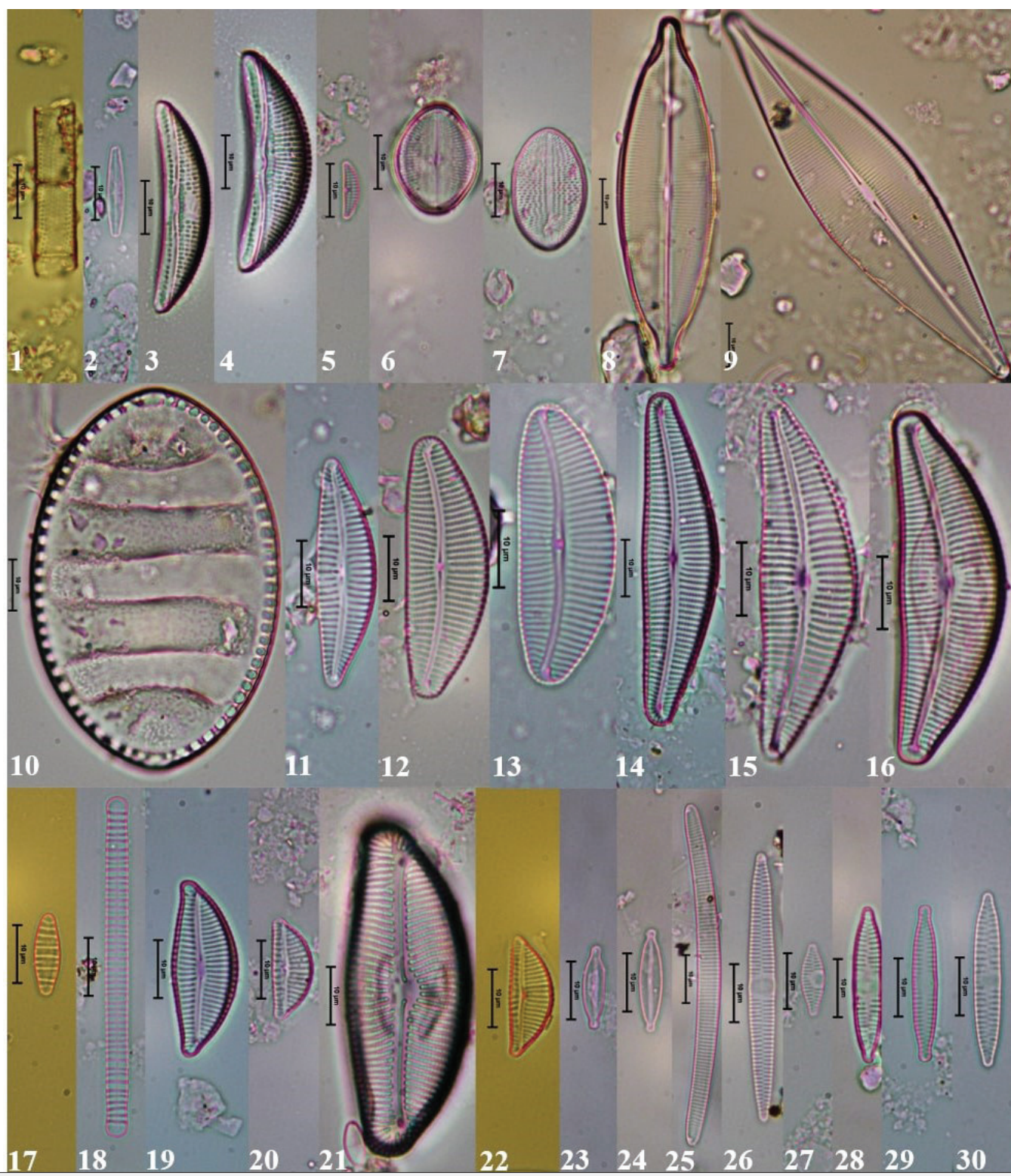

Figure 3. 1) Aulacoseira granulata, 2) Achnanthidium sp., 3) Amphora copulata, 4) A. ovalis, 5) A. pediculus, 6) Cocconeis pediculus, 7) $C$. placentula, 8) Craticula cf. ambigua, 9) C. cuspidata, 10) Cymatopleura elliptica, 11) Cymbella affinis, 12) C. cantonatii, 13) C. compacta, 14) C. lange-bertalotii, 15) C. neocistula, 16) C. tumida, 17) Diatoma mesodon, 18) D. tenuis, 19) Encyonema auerswaldii, 20) E. minutum, 21) E. prostratum, 22) E. ventricosum, 23) Encyonopsis minuta, 24) E. subminuta, 25) Eunotia bilunaris, 26) Fragilaria cf. capucina, 27) F. perminuta, 28) F. vaucheriae, 29) Fragilaria sp.1, 30) Fragilaria sp.2.

hungarica were observed only in this season, and their relative abundance is less than $4 \%$.

In the August sampling, the highest number of species was determined at station 5 (27 species), and the least number of species were determined at station 3 ( 11 species). Achnanthidium sp., Cocconeis placentula, Fragilaria perminuta, and Navicula reichardtiana were observed in all stations. In terms of relative abundance, in this period, C. affinis (27\%) at station 1, C. placentula (30\%) at station 2, Achnanthidium sp. (67\%) at station 3, C. placentula (82\%) at station 4, and E. auerswaldii (43\%) at station 5 (Figure 6c) were strikingly dominant. Aulacoseira granulata, the only member of centric diatom observed in the study in this sampling period, Amphora copulata, Craticula of. ambigua, Craticula cuspidata, Gomphonema acuminatum, G. augur, Planothidium lanceolatum, and Tryblionella apiculata from pennate diatoms were found only in this season, and the relative abundance of species other than P. lanceolatum (5\%) remained below $1 \%$.

In November, no Phragmites sp. were encountered. For this reason, sampling was performed only at station 2 , and 25 


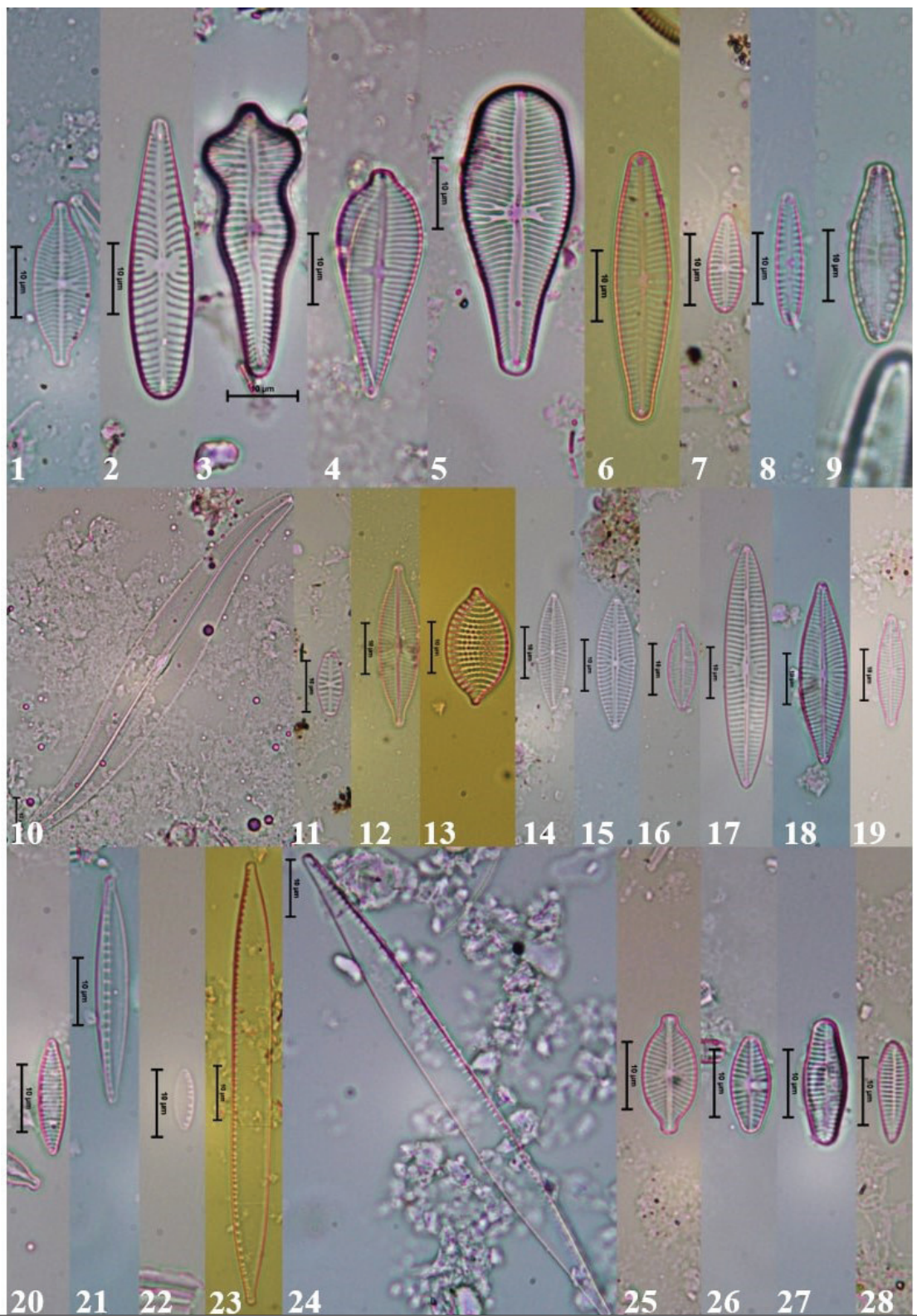

Figure 4. 1) Geissleria decussis, 2) Gomphonella olivacea, 3) Gomphonema acuminatum, 4) G. augur, 5) G. italicum, 6) G. micropus, 7) G. minuta, 8) G. pumilum, 9) Gomphonema sp., 10) Gyrosigma kuetzingii, 11) Hippodonta hungarica, 12) Navicula capitoradiata, 13) N. compressa, 14) N. cryptotenelloides, 15) N. novaesiberica, 16) N. reichardtiana, 17) N. tripunctata, 18) N. trivialis, 19) N. veneta, 20) Nitzschia amphibia, 21) N. dissipata, 22) N. inconspicua, 23) N. intermedia, 24) N. recta, 25) Placoneis sp., 26) Planothidium frequentissimum, 27) $P$. lanceolatum, 28) Rhoicosphenia abbreviata.

epiphytic diatom species were found. Fragilaria perminuta (31\%) and Navicula tripunctata (29\%) were identified as the dominant species in this period (Figure 6d). Navicula compressa, Nitzschia inconspicua, N. recta, and Rhoicosphenia abbreviata were also found only in this period, and the relative abundance of the species was observed to be below $1 \%$.

\section{Statistical Evaluation of Data}

In order to reveal the relationship between the number of species of epiphytic diatoms in the reservoir and environmental parameters, Spearman's rank correlation was performed (Table 2 ), and it was determined that there was only a positive correlation between the number of epiphytic diatom species and the conductivity $(p<0.05)$.

Ordination analyses were run to reveal the relationship between epiphytic diatom species and ecological variables (Figure 7). In the CCA analysis performed, the results show that environmental factors are effective in the distribution of epiphytic diatom assemblages. The most effective explanatory factors 

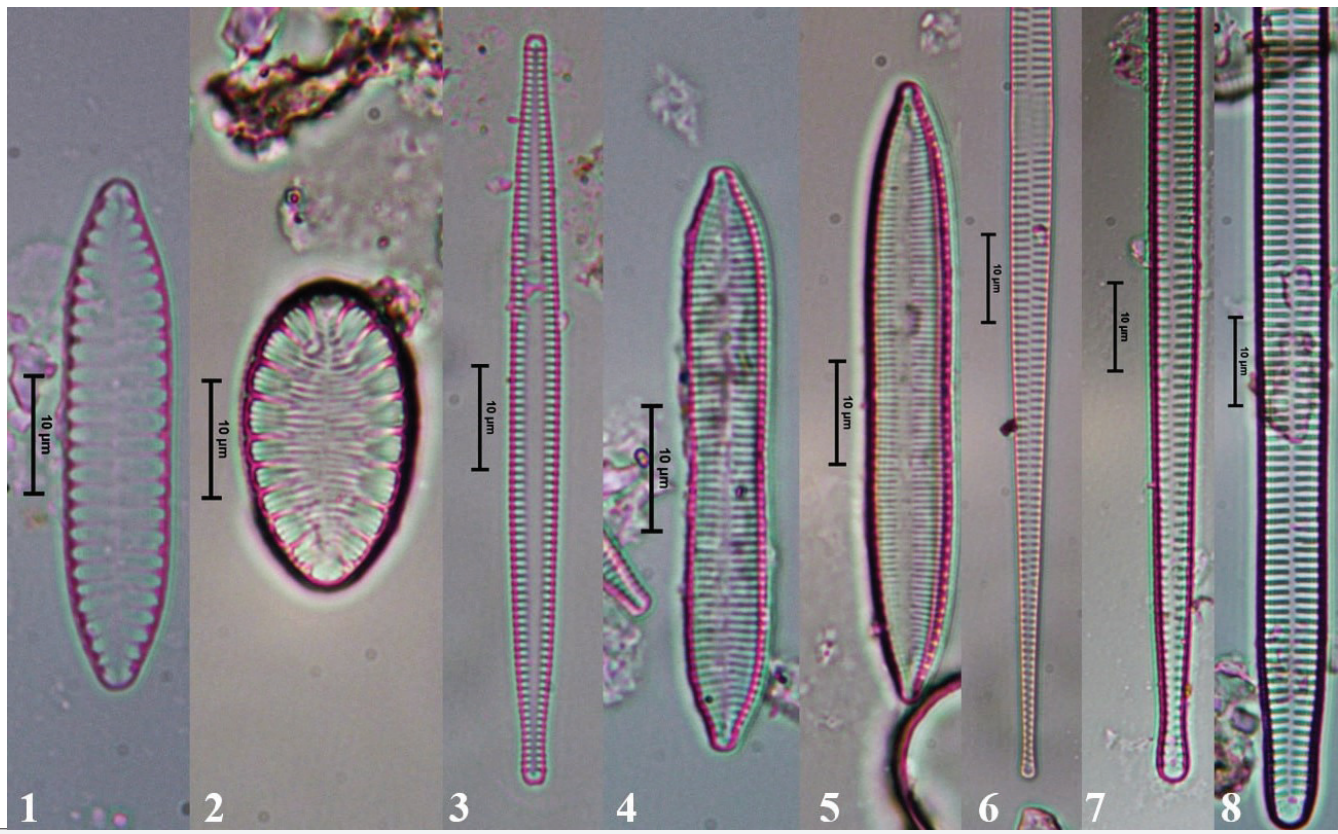

Figure 5. 1) Surirella angusta, 2) S. brebissonii, 3) Tabularia fasciculata, 4) Tryblionella apiculata, 5) T. hungarica, 6) Ulnaria acus, 7) U. biceps, 8) U. ulna.

Table 1. The list of epiphytic diatoms in the Büyükçekmece Reservoir ("*” shows the new record species in the reservoir).

\begin{tabular}{|c|c|c|c|c|}
\hline Taxa & February & May & August & November \\
\hline \multicolumn{5}{|l|}{ Centric diatoms } \\
\hline Aulacoseira granulata (Ehrenberg) Simonsen, 1979 & & & + & \\
\hline \multicolumn{5}{|l|}{ Pennate diatoms } \\
\hline Achnanthidium sp. & & + & + & + \\
\hline *Amphora copulata (Kützing) Schoeman\&Archibald, 1986 & & & + & \\
\hline Amphora ovalis (Kützing) Kützing, 1844 & & + & + & \\
\hline *Amphora pediculus (Kützing) Grunow, 1875 & & & + & + \\
\hline${ }^{*}$ Cocconeis pediculus Ehrenberg, 1838 & & + & + & + \\
\hline Cocconeis placentula Ehrenberg, 1838 & + & + & + & + \\
\hline${ }^{*}$ Craticula cf. ambigua (Ehrenberg) Mann, 1990 & & & + & \\
\hline Craticula cuspidata (Kützing) Mann, 1990 & & & + & \\
\hline Cymatopleura elliptica (Brébisson) Smith, 1851 & & & + & + \\
\hline Cymbella affinis Kützing, 1844 & + & + & + & + \\
\hline Cymbella cantonatii Lange-Bertalot, 2002 & + & & & \\
\hline Cymbella compacta Østrup, 1910 & & + & + & \\
\hline${ }^{*}$ Cymbella lange-bertalotii Krammer, 2002 & & + & + & \\
\hline *Cymbella neocistula Krammer, 2002 & + & & + & \\
\hline Cymbella tumida (Brébisson) Van Heurck, 1880 & & + & + & \\
\hline
\end{tabular}


Table 1 (Continued)

Taxa

February May August November

Pennate diatoms (Continued)

*Diatoma mesodon (Ehrenberg) Kützing, 1844

*Diatoma tenuis Agardh, 1812

*Encyonema auerswaldii Rabenhorst, 1853

*Encyonema minutum (Hilse) Mann, 1990

Encyonema prostratum (Berkeley) Kützing, 1844

Encyonema ventricosum (Agardh) Grunow, 1875

*Encyonopsis minuta Krammer\&Reichardt, 1997

Encyonopsis subminuta Krammer\&Reichardt, 1997

${ }^{*}$ Eunotia bilunaris (Ehrenberg) Schaarschmidt, 1880

*Fragilaria cf. capucina Desmaziéres, 1830

*Fragilaria perminuta (Grunow) Lange-Bertalot, 2000

*Fragilaria vaucheriae (Kützing) Petersen, 1938

Fragilaria sp.1

Fragilaria sp.2

*Geissleria decussis (Østrup) Lange-Bertalot\&Metzeltin, 1996

Gomphonella olivacea (Hornemann) Rabenhorst, 1853

Gomphonema acuminatum Ehrenberg, 1832

Gomphonema augur Ehrenberg, 1841

*Gomphonema italicum Kützing, 1844

*Gomphonema micropus Kützing, 1844

*Gomphonema minuta Fusey, 1953

*Gomphonema pumilum (Grunow) Reichardt\&Lange-Bertalot, 1991

Gomphonema sp.

*Gyrosigma kuetzingii (Grunow) Cleve, 1894

*Hippodonta hungarica (Grunow) Lange-Bertalot, Metzeltin\&Witkowski, 1996

$+$

$\begin{array}{llll}+ & & \\ + & + & + & \\ + & + & + & + \\ + & + & + & + \\ + & + & + & \end{array}$

$\begin{array}{llll}+ & & & \\ & + & & + \\ + & + & + & + \\ + & + & + & +\end{array}$

$+$

$+\quad+\quad+$

$+$

$+\quad+$

$+$

$+$

$+$

$+$

$+$

$+$

$+\quad+$

$+\quad+$

$+$

$\begin{array}{llll} & + & + & \\ & + & & \\ + & + & + & + \\ & + & & \\ & + & + & + \\ + & + & + & + \\ + & + & + & +\end{array}$


Table 1 (Continued)

\begin{tabular}{|c|c|c|c|c|}
\hline Taxa & February & May & August & November \\
\hline \multicolumn{5}{|l|}{ Pennate diatoms (Continued) } \\
\hline *Navicula veneta Kützing, 1844 & & + & + & + \\
\hline *Nitzschia amphibia Grunow, 1862 & & + & + & \\
\hline${ }^{*}$ Nitzschia dissipata (Kützing) Rabenhorst, 1860 & + & + & & + \\
\hline *Nitzschia inconspicua Grunow, 1862 & & & & + \\
\hline *Nitzschia intermedia Hantzsch in Cleve\&Grunow, 1880 & + & & & \\
\hline *Nitzschia recta Hantzsch in Rabenhorst, 1862 & & & & + \\
\hline Placoneis sp. & & & + & \\
\hline *Planothidium frequentissimum (Lange-Bertalot) Lange-Bertalot, 1999 & & & + & \\
\hline Planothidium lanceolatum (Brébisson in Kützing) Lange-Bertalot, 1999 & & & + & \\
\hline Rhoicosphenia abbreviata (Agardh) Lange-Bertalot, 1980 & & & & + \\
\hline Surirella angusta Kützing, 1844 & + & & & \\
\hline Surirella brebissonii Krammer\&Lange-Bertalot, 1987 & + & + & + & \\
\hline *Tabularia fasciculata (Agardh) Williams\&Round, 1986 & + & & & \\
\hline *Tryblionella apiculata Gregory, 1857 & & & + & \\
\hline Tryblionella hungarica (Grunow) Frenguelli, 1942 & & + & & \\
\hline Ulnaria acus (Kützing) Aboal, 2003 & & + & & \\
\hline Ulnaria biceps (Kützing) Compère, 2001 & + & & & \\
\hline Ulnaria ulna (Nitzsch) Compère, 2001 & + & + & + & \\
\hline Total Number of Species in Seasons & 28 & 38 & 43 & 25 \\
\hline Total Number of Species & 66 & & & \\
\hline
\end{tabular}

are temperature and conductivity, respectively, and these variables played an important role in the distribution of the species $(p<0.05)$. It was determined that temperature, conductivity, $\mathrm{DO}$, and $\mathrm{pH}$ had a strong positive correlation with Axis 1, and salinity had a strong positive correlation with Axis $2(p<0.05)$. According to CCA, it was revealed that the environmental variables measured in this study did not affect the distribution of $C$. affinis and C. lange-bertalotii. It was determined that temperature was positively related with $E$. minuta, G. kuetzingii, and $N$. veneta while being negatively related with $N$. dissipata and $U$. ulna. In addition, conductivity had a positive correlation with $E$. minuta and $E$. ventricosum while having a negative correlation with C. compacta and $U$. ulna. Furthermore, this analysis shows that $E$. minuta, N. trivialis, and $N$. veneta are negatively affected by $\mathrm{DO}$ and $\mathrm{pH}$, and F. vaucheriae, G. pumilum, N. dissipata, and S. brebissonii by salinity.

In order to reveal the epiphytic diatom species diversity, the Shannon-Weaver $\left(H^{\prime}\right)$ diversity index was employed based on the number of species and individuals in all sampling periods (Figure 8). Due to the low water level in November, only station $2\left(H^{\prime}=3.13\right)$ could be sampled, so other stations were not included in the measurement. Considering all the sampling periods, it was determined that the index varied between 1.24 (August) and 3.38 (May).

Clustering analyses were used to determine the similarities of the stations investigated in Büyükçekmece Reservoir. Accordingly, while investigating the similarities of the stations in terms of biotic variables, Bray-Curtis similarity analysis was employed (Figure 9a), and it was determined that the highest similarity was between stations 1 and 2 (69.1\%). The lowest similarity rate was observed between stations 2 and 3 (44.5\%). It was also noted that station 3 had a low similarity rate with other stations $(<54 \%)$ and differed from other stations. By using Euclidean distance (ED) to determine the similarity between the stations in terms of ecological variables (Figure 9b), stations 2 and 4 were found to be the closest stations $(E D=4.8)$, and stations 3 and 5 were found to be 
(a)

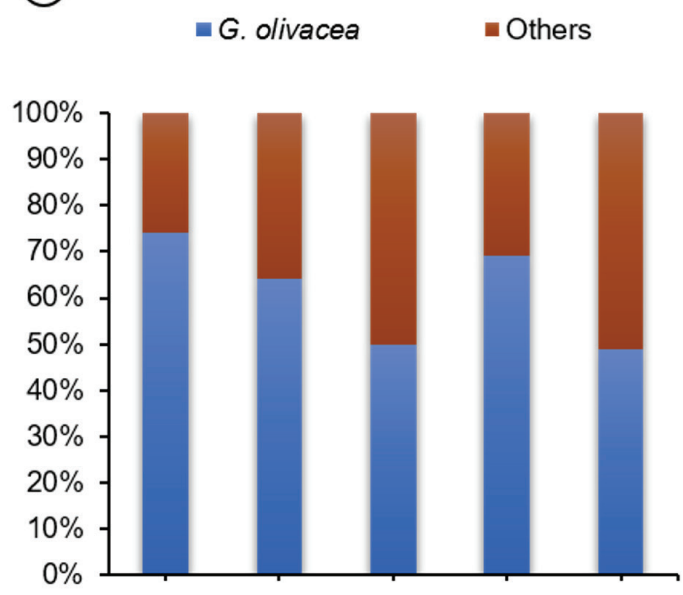

(C)

$\begin{array}{ll}\square \text { Achnanthidium sp. } & \square \text { C. placentula } \\ \square \text { C. affinis } & \square \text { C. lange-bertalotii } \\ \square \text { E. auerswaldii } & \square \text { E. subminuta } \\ \square \text { F. perminuta } & \quad \text { Others }\end{array}$

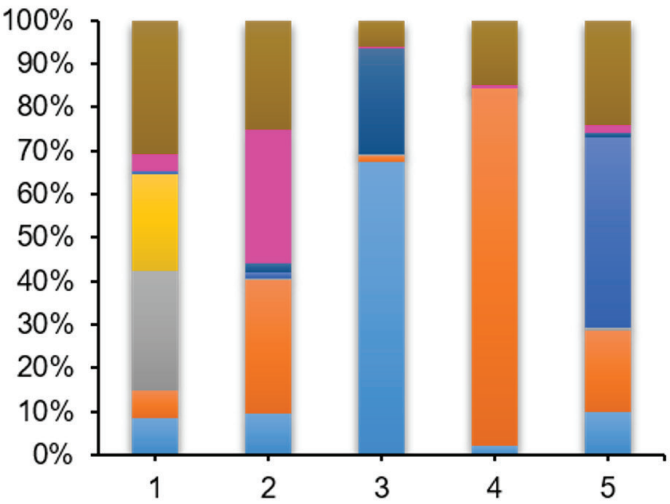

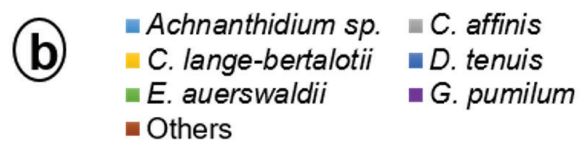

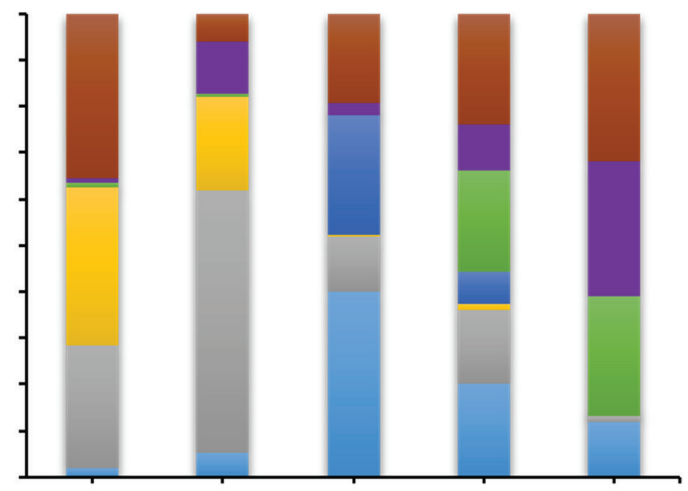

(d)

Figure 6. The relative abundance of the dominant epiphytic diatom species (> 20\%) in the Büyükçekmece Reservoir (a) February, b) May, c) August and d) November; Cocconeis placentula: C. placentula, Cymbella affinis: C. affinis, Cymbella lange-bertalotii: C. lange-bertalotii, Diatoma tenuis: D. tenuis, Encyonema auerswaldii: E. auerswaldii, Encyonopsis subminuta: E. subminuta, Fragilaria perminuta: F. perminuta, Gomphonella olivacea: G. olivacea, Gomphonema pumilum: G. pumilum, Navicula tripunctata: N. tripunctata).

Table 2. Spearman's rank correlation between environmental parameters and epiphytic diatoms ( ${ }^{* *} p<0.01,{ }^{*} p<0.05, H^{\prime}:$ ShannonWeaver diversity index).

\begin{tabular}{|c|c|c|c|c|c|c|}
\hline & Temperature & Salinity & Conductivity & Dissolved oxygen & pH & Epiphytic diatoms \\
\hline Salinity & -0.236 & & & & & \\
\hline Conductivity & $0.553^{*}$ & 0.355 & & & & \\
\hline Dissolved oxygen & $-0.541^{*}$ & -0.126 & $-0.691^{* *}$ & & & \\
\hline pH & -0.287 & -0.417 & $-0.651^{* *}$ & $0.784^{* *}$ & & \\
\hline Epiphytic diatoms & 0.276 & -0.051 & $0.587^{*}$ & -0.264 & -0.169 & \\
\hline$H^{\prime}$ & 0.062 & -0.037 & 0.370 & -0.118 & -0.168 & $0,845^{* *}$ \\
\hline
\end{tabular}




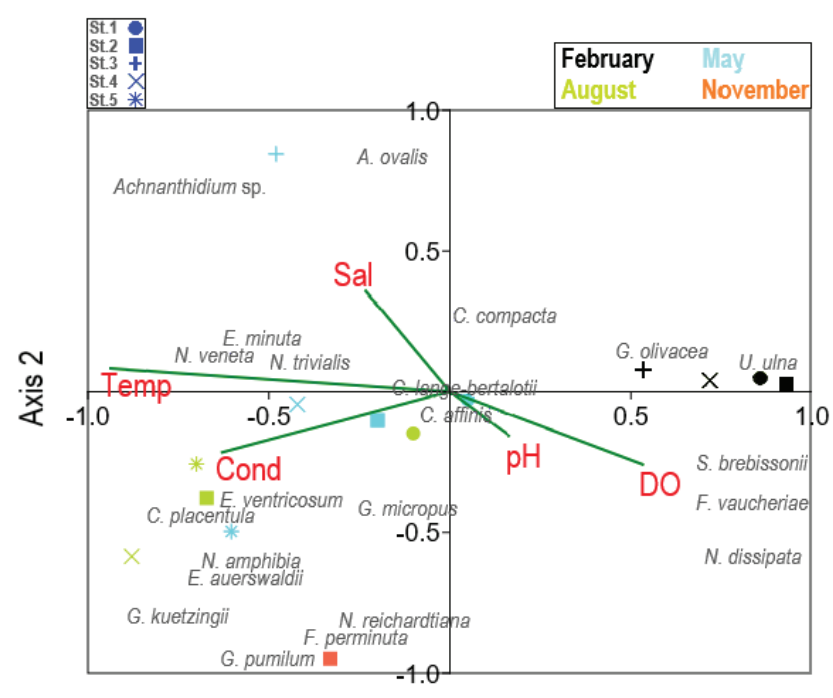

Axis 1

Figure 7. CCA results showing relationships between environmental variables and epiphytic diatom taxa distributions $(p<$ 0.05). (Cond: Conductivity, DO: Dissolved oxygen, Sal: Salinity, Temp: Temperature; Amphora ovalis: A. ovalis, Cocconeis placentula: C. placentula, Cymbella affinis: C. affinis, Cymbella compacta: C. compacta, Cymbella lange-bertalotii: C. lange-bertalotii, Encyonema auerswaldii: E. auerswaldii, Encyonopsis minuta: E. minuta, Encyonema ventricosum: E. ventricosum, Fragilaria perminuta: F. perminuta, Fragilaria vaucheriae: F. vaucheriae, Gomphonella olivacea: G. olivacea, Gomphonema micropus: G. micropus, Gomphonema pumilum: G. pumilum, Gyrosigma kuetzingii: G. kuetzingii, Navicula reichardtiana: N. reichardtiana, Navicula trivialis: N. trivialis, Navicula veneta: N. veneta, Nitzschia amphibia: $N$. amphibia, Nitzschia dissipata: N. dissipata, Surirella brebissonii: S. brebissonii, Ulnaria ulna: U. ulna).

the most distant to each other $(E D=8.1)$. In terms of Euclidean Distance, it was observed that station 3 differed from other stations, similar to the Bray-Curtis similarity analysis.

\section{The Status of Büyükçekmece Reservoir in Terms of Water Quality Parameters}

According to the measured DO and conductivity in the study, it was aimed to ascertain the ecological water quality class and trophic level of the reservoir (Table 3). According to the Surface

\section{Shannon-Weaver Diversity Index}

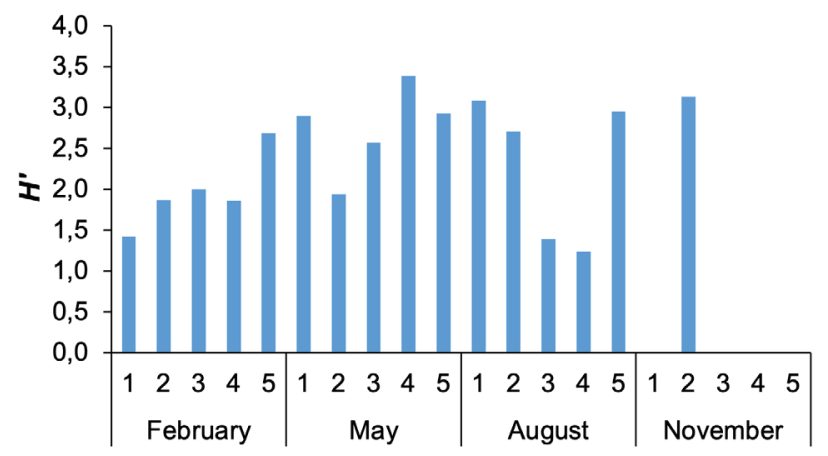

Figure 8. Shannon-Weaver diversity index in the sampling periods.

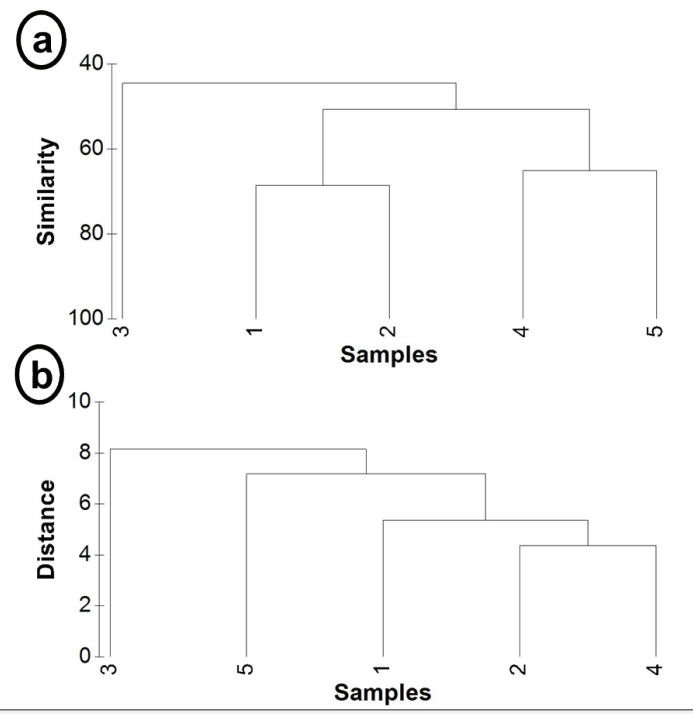

Figure 9. Dendrograms of cluster analysis based on BrayCurtis similarity index (a) and Euclidean Distance (b) in the Büyükçekmece Reservoir.

Water Quality Control Regulation (12) considering the conductivity and DO values, the reservoir is of very good (I) and good

Table 3. Ecological water quality status and trophic level of the lake according to conductivity and dissolved oxygen values (Classification: "I" Very good, "II" good, "III" Moderate; Trophic Level: "O" oligotrophic, "M" mesotrophic, "E" Eutrophic").

\begin{tabular}{lcccccccccccccc}
\hline & \multicolumn{3}{c}{ Conductivity } & \multicolumn{3}{c}{ Dissolved Oxygen } & \multicolumn{4}{c}{ Trophic Status (DO) } \\
\hline Stations & Feb & May & Aug & Nov & Feb & May & Aug & Nov & Feb & May & Aug & Nov \\
\hline $\mathbf{1}$ & I & II & II & II & I & II & I & I & O & O & O & O \\
\hline $\mathbf{2}$ & I & I & II & II & I & I & I & I & O & O & O & O \\
\hline $\mathbf{3}$ & II & II & II & II & I & II & I & I & O & O & O & O \\
\hline $\mathbf{4}$ & I & II & II & II & I & I & I & III & O & O & O & M \\
\hline 5 & I & II & II & III & I & I & III & III & O & O & M & E \\
\hline
\end{tabular}


(II) quality, but in terms of DO values in some seasons and stations (August and November), it is at the moderate (III) class water quality level. At the same time, when the trophic level of the lake was evaluated according to DO, it was determined that oligotrophic conditions prevailed throughout the study, and the eutrophic situation prevailed only at station 5 in the November sampling period. When the reservoir is classified according to $H^{\prime}$ values, stations 1, 2, and 4 were poor, stations 3 and 5 were moderate in February; stations 1, 2, 3, and 5 were moderate, and station 4 was good in May; stations 3 and 4 were poor, stations 2 and 5 were moderate, and station 1 was good in August while station 2 was of good status in November.

\section{DISCUSSION}

In this study conducted seasonally on epiphytic diatoms in Büyükçekmece Reservoir, 66 species were identified. 36 of the identified species (54.4\%) are new records for the reservoir, and some genera (Eunotia, Geissleria, Hippodonta, and Tabularia) were first encountered in this study in the reservoir. Also, in addition to these 36 new species records, the species which were reported by Balkis-Ozdelice et al. (24) as new record species for the reservoir (Cymbella cantonatii, C. compacta, Encyonopsis subminuta, Navicula trivialis, and Surirella brebissonii), were also found in this study.

In Büyükçekmece Reservoir, only one study covering epiphytic diatoms was carried out (18), and 42 species were reported. Of the species acquired by Temel (18), 13 species (13.7\%) were common, 29 species (30.5\%) were found only in the study of Temel (18), and 53 species (55.8\%) were detected only in the present study. According to these two studies, the number of epiphytic diatom species of the reservoir was determined to be 95 . In addition to epiphytic algae in the reservoir, epilithic, epipelic, and phytoplanktonic organisms in the water column were also analysed (17-24). The species obtained from all these studies are presented in a list (24). According to Balkis-Ozdelice et al. (24), a total of 333 phytoplankton species were reported in the reservoir, and it was stated that 128 of these species were reported to be composed of diatoms. By adding 36 epiphytic diatom species obtained in this study to the list, this number was updated as 164 for diatoms and 369 for total phytoplankton. When considering the epiphytic diatom studies carried out in lakes and reservoirs in Turkey; 39 epiphytic diatom species from Karkamış and Birecik Reservoirs (46), 31 from Lake Liman (47), 66 from Lake Gala (48), and 61 from Lake Mogan (49) have been reported. Accordingly, it has been determined that Büyükçekmece Reservoir has a similar number of epiphytic diatom species with other lakes and reservoirs.

While Temel (18) noted that Cocconeis placentula, Navicula tripunctata (=N. gracilis), and Nitzschia palea were common and numerous, $C$. placentula and $N$. tripunctata were widely observed in our study whereas N. palea was not found. In addition, in the present study, C. affinis, E. minuta, F. perminuta, F. vaucheriae, G. olivacea, G. minuta, N. reichardtiana, N. tripunctata, and $N$. trivialis were widely recorded (in all seasons). Additionally, $E$. minuta and G. pumilum, which are reported to be rare species for Turkish freshwater diatom flora (50), are commonly encountered in the reservoir, and E. subminuta, another rare species in Turkey, was rarely observed in the Büyükçekmece Reservoir.

In this study, it was observed that pennate diatom members from epiphytic diatoms are dominant, especially $G$. olivacea in the February sampling, C. affinis in May, Achnanthidium sp. and C. placentula in August, and F. perminuta in November. The dominance of pennate diatoms in the epiphytic habitat compared to centric diatoms is similar to the previous study in the reservoir (18), as well as with the studies performed in other lakes (51-53). In addition, Round (54) reported that Fragilaria, Cocconeis, Gyrosigma, Caloneis, Navicula, Amphora, Cymbella, and Nitzschia are very common in calcareous waters while Pinnularia and Neidium are very common in acidic waters. In addition, Round $(55,56)$ reported that in addition to these genera, Cymatopleura elliptica species increased in neutral and slightly alkaline waters, and Amphora ovalis increased significantly in alkaline waters. In this study, the prevalence of the common species in calcareous waters and the absence of Pinnularia and Neidium, representing acidic environments in epiphytic habitats, showed that the environment was calcareous and alkaline. One of the ecological variables, the $\mathrm{pH}$ value between 7.49 and 8.28 also supports this finding.

As is known, diatoms are used as indicators of $\mathrm{pH}$, conductivity, salinity, and trophic level (57). Lange-Bertalot et al. (58) stated that Navicula veneta, which was also observed in this study, is one of the diatom types that can be used as a pollution indicator, but the relative abundance of this species in the stations analysed in Büyükçekmece Reservoir remained below 1\%. Overall in the study, G. olivacea is the species that increased its abundance at low temperature and high $\mathrm{pH}$ values. Similarly, Koçer and Şen (59) stated in their study in Lake Hazar that this species is dominant under similar ecological conditions. Since the relationship of this species with temperature and $\mathrm{pH}$ could not be revealed in the CCA analysis, it was not possible to conclude whether it could be used as an indicator or not. Also, in CCA analysis, it was determined that $N$. veneta had a positive relationship with temperature and $E$. ventricosa had a positive relationship with conductivity $(p<0.05)$. These species can be considered as potential indicators, but further studies are needed to verify their status as indicator species. Also, according to ordination analysis, temperature and conductivity were revealed to be the main factors affecting diatom distribution.

Surirella brebissonii, F. vaucherii, and N. dissipata, which are epiphytic diatom species, were negatively correlated with temperature and salinity; C. compacta and U. ulna were negatively correlated with conductivity; E. minuta, $N$. trivalis, and $\mathrm{N}$. veneta were negatively correlated with $\mathrm{pH}$ and DO. With the spring period, an increase in temperature and conductivity was observed, and it was determined that $C$. affinis and C. lange-bertalotii, which are dominant species in this period, were not affected by the ecological variables measured in the study. However, Kelly et al. (60) reported 
that $C$. affinis could be specified as a high-quality indicator type for moderately alkaline lakes. In this study, $\mathrm{pH}$ varied between 7.91 and 8.05 during the periods when C. affinis was dominant. With temperature conditions reaching the optimum level $\left(\sim 25^{\circ} \mathrm{C}\right)$ during the summer period, Achnanthidium sp. and C. placentula became dominant. Among these species, C. placentula was found to show a positive correlation with temperature and conductivity. It was noted that this species was not observed under $0.500 \mathrm{mS} / \mathrm{cm}$ conductivity value and reached the maximum abundance at station 4 in August when the highest temperature value in the study was determined. Kindt and Small (61) reached similar results with this study and stated that the abundance of $C$. placentula increased with the increase in temperature.

Van Dam et al. (62) stated that the species belonging to the genus Cymbella and Eunotia were found in regions with high dissolved oxygen concentrations. Similarly, in the Büyükçekmece Reservoir, DO has reached a high concentration (18.4 mg/L) at station 2 in May while the relative abundance of $C$. affinis and $C$. lange-bertalotii at this station reached $76 \%$. In addition, Eunotia bilunaris was observed only in the May sampling where the DO concentration was high. Cox (63) reported that Navicula capitatoradiata and $N$. veneta were more common in waters with high conductivity. Contrary to this finding, both species were found abundant in February and May samples (compared with other seasons), where the conductivity was low in the Büyükçekmece Reservoir. Reimer et al. (64) stated that C. placentula is a cosmopolitan species due to its high tolerance to the change of environmental factors. As similar, C. placentula was observed in almost every season in this study.

As it is known, as the temperature increases, the solubility of gases decreases. It was observed that the dissolved oxygen concentration increased with the decrease in temperature in cold periods (February, November) in the Büyükçekmece Reservoir. Similar results were found in a study conducted in Tasmanlı Pond (65). The number of species was also found to be high in May and August, which represent warm periods. However, in a study conducted in Topçu Lake (51), a decrease in the number of species was reported in July and August (in warm periods). This situation reveals that environmental factors may decrease or increase the number of species.

When the evaluation was made on the basis of stations, it was determined that station 3 was represented with fewer species than other stations in terms of the number of diatom species in the reservoir. Bray-Curtis and Euclidean Distance among the cluster analysis were applied in the study, and it was revealed that station 3 was separated from the other stations according to both analyses. Also, according to Spearman's rank correlation, a positive relationship was observed between conductivity and the number of epiphytic diatom species $(p<0.05)$. While the highest conductivity values in February and May were reached at station 3 , there was no increase observed in terms of the number of species. In fact, it is remarkable that only 8 cells belonging to 5 species were found in the February sample.
Shannon-Weaner diversity index $\left(H^{\prime}\right)$, used for determining the structure of the communities, varied between 1.24 and 3.38 in the study. The lowest values in the study were obtained in August. During this period, Achnanthidium sp. (St.3, 67\%) and C. placentula (St.4, 82\%) were dominant species, and this situation caused a decrease in $H^{\prime}$ values. Also, it was determined that the diversity at station 5 , which is located in the north of the reservoir and close to the stream, did not show a significant change seasonally. Molvær et al. (45) classified waters for the ecological quality. According to this classification, Büyükçekmece Reservoir was generally in poor and moderate status, and in some sampling periods, it was found to be in good status (St.4 in May, St.1 in August, and St.2 in November). In addition, it was observed that $H^{\prime}$ values obtained from studies on epiphytic diatoms in other freshwater resources ranged from 0.867 to $1.427(47,48)$. Accordingly, it was revealed that the diversity of Büyükçekmece Reservoir is at a higher level than the other sources.

\section{CONCLUSION}

As a result, this study aimed to determine the epiphytic diatoms and abundance conditions in the reservoir, and newly recorded species for the lake were reported. In the reservoir, it was also reported that according to the conductivity and DO values, the lake is of very good (I) and good (II) quality. Also, in terms of DO values, it was observed that the reservoir was oligotrophic during the February and May sampling periods, station 5 was mesotrophic, other stations were oligotrophic during the August sampling period, stations 1, 2, and 3 were oligotrophic, station 4 was mesotrophic, and station 5 was eutrophic during the November sampling period. Eutrophication conditions have occurred since station 5 is located close to the Karasu Stream, which is the biggest nutrient source of the reservoir and has been reported to carry a significant amount of nutrient load, and the occupancy rate of the reservoir had decreased to $40 \%$ during the November sampling period. Balkis-Ozdelice et al. (24) proposed that the phosphorus intake to Büyükçekmece Reservoir be controlled. Also, according to $H^{\prime}$ classification, Büyükçekmece Reservoir was generally in poor and moderate status. For these reasons, it is necessary to monitor the ecological quality status of the reservoir with monitoring studies.

Financial Disclosure: This study was supported by TÜBITAK with Project No: 118 Y347.

Conflict of Interest: The authors declare that they have no conflicts of interest.

Author Contributions: Conception/Design of study: T.O.A., N.B.O.; Data Acquisition: T.O.A., N.B.O., T.D.; Data Analysis/Interpretation: : T.O.A., N.B.O., T.D., C.N.S.; Drafting Manuscript:T.O.A., N.B.O., T.D., C.N.S.; Final Approval and Accountability: T.O.A., N.B.O., T.D., C.N.S.

Acknowledgements: The authors are grateful to Dr. Husamettin Balkis, Dr. Muharrem Balci and Dr. Benin TokluAlicli from Istanbul University for their valuable assistance 
in field sampling. They also thank Elif Yilmaz for her support in preparing diatom frustules. In addition, the authors thank TÜBITAK (BIDEB-2237, Project No: 1129B371901423) for their contribution to the implementation of ordination analysis.

\section{REFERENCES}

1. Medlin LK, Kooistra WHCF, Gersonde R, Sims PA, Wellbrock U. Is the origin of diatoms related to the end-Permian mass extinction? Nova Hedwigia 1997; 65: 1-11.

2. Round FE, Crawford RM, Mann DG. Biology of diatoms, the diatoms: Biology and morphology of the genera. Sandgren CD, editor. Cambridge: Cambridge University Press; 1990. 746 p.

3. Ács É, Szabó K, Tóth B, Kiss KT. Investigation of benthic algal communities, especially diatoms of some Hungarian streams in connection with reference conditions of the Water Framework Directives. Acta Bot Hung 2004; 46 (3-4): 255-78.

4. Soininen J, Paavola R, Muotka T. Benthic diatom communities in boreal streams: community structure in relation to environmental and spatial gradients, Ecography 2004; 27(3): 330-42.

5. Cumming BF, Wilson SE, Hall RI, Smol JP. Diatoms from British Columbia (Canada) Lakes and their relationship to salinity, nutrients and other limnological variables. Bibliotecha Diatomalogica 1995. $207 \mathrm{p}$.

6. Battarbee RW, Charles DF, Dixit SS, Renberg I. Diatoms as indicators of surface water acidity. Stoermer EF, Smol JP, editors. The Diatoms: Applications for the enviromental and earth sciences. Cambridge: Cambridge University Press; 1999. pp. 98-121.

7. John J. Bioassessment on health of aquatic systems by the use of diatoms. Ambasht RS, Ambasht NK, editors. Modern Trends in Applied Aquatic Ecology. New York, USA: Kluwer Academic Publications; 2003. pp. 1-20.

8. Taylor JC, Harding WR, Archibald CGM. An illustrated guide to some common diatom species from South Africa. Gezina, South Africa: Water Research Commission; 2007. Report No: 282/07.

9. Bozarth A, Maier UG, Zauner S. Diatoms in biotechnology: modern tools and applications. Appl Microbiol Biotechnol 2009; 82: 195-201.

10. Official Journal of the European Communities. Directive 2000/60/ EC of the European Parliament and of the Council, establishing a framework for community action in the field of water policy. The European Parliament and the Council of the European Union 2000; 327: 1-73.

11. Official Gazette of the Republic of Turkey. Water pollution control regulations. Official Gazette of the Republic of Turkey 2004; No: 25687.

12. Official Gazette of the Republic of Turkey. Surface water quality management regulation. Official Gazette of the Republic of Turkey 2016; No: 29797.

13. Stener-Kovács C, Buczkó K, Hajnal É, Padisák J. Epiphytic, littoral diatoms as bioindicators of shallow lake trophic status: Trophic Diatom Index for Lakes (TDIL) developed in Hungary. Hydrobiologia 2007; 589: 141-54.

14. Dalkıran N, Zünbülgil B, Karacaoğlu D, Dere Ş. Uluabat gölü epifitik diyatomelerinin uzun dönemdeki değişimleri. LimnoFish 2016; 2(3): 153-63.

15. Sanal M, Demir N. Use of the epiphytic diatoms to estimate the ecological status of Lake Mogan. Appl Ecol Environ Sci 2018; 16(3): 3529-43.

16. Solak CN, Çetin T, Karaaslan Y, Kaleli A, Yılmaz E, Duran M, Kıvanç G, Kimençe, T, Aynur-Koyunoğlu, Ş., Çankaya, B.F., Yılmaz-Aşık, D. Common diatoms of phytobenthos in Gediz River Basin. Turkish Journal of Water Science \& Management 2019; 3(2): 58-70.
17. Temel M. Büyükçekmece Gölü Bentik Alg Florası, Süleyman Demirel Univ. Eğirdir Su Ürün. Fak. Derg. 1996-1997; 5: 173-90.

18. Temel M. Büyükçekmece Gölü bentik alg florası, Kısım II: Epilitik ve epifitik alg toplulukları. In: X. National Fisheries Symposium, Adana: 22-24 September 1999; 877-86.

19. Temel M. The phytoplankton of Lake Büyükçekmece, İstanbul, Turkey, Pak J Bot 2002; 34(1): 81-92.

20. Aktan-Turan Y, Aykulu G, Albay M, Okgerman H, Akçaalan R, Gürevin C, Dorak Z. Büyükçekmece Gölü'nde aşırı artış gösteren fitoplankterlerin gelişimini kontrol eden faktörlerin araştırılması. TÜBITAK, Ankara. 2006. Report No: 103Y127.

21. Aktan Y, Gürevin C, Dorak Z. The effect of environmental factors on the growth and size structure of two dominant phytoplankton species in Büyükçekmece Reservoir (ìstanbul, Turkey). Turk J Biol 2009; 33: 335-40.

22. Gulecal Y, Temel M. Water quality and phytoplankton diversity in Büyükçekmece Watershed, Turkey. J Water Resource Prot 2014; 6: 55-61.

23. Yilmaz N. Water quality assessment based on the phytoplankton composition of Buyukcekmece Dam Lake and its influent streams (Istanbul), Turkey. Desalin Water Treat 2019; 159: 3-12.

24. Balkis-Ozdelice N, Solak CN, Durmus T. The use of phytoplankton communities to determination of the ecological status of Büyükçekmece Dam-Lake and the investigation of water quality problems. TÜBITAK, Ankara; 2020. Report No: 118Y347.

25. Demir N, Atay D. Kurtboğazı ve Çamlıdere Baraj Göllerinin Fitoplanktonu. In: X. National Fisheries Symposium, 1999; p. 577-87.

26. Directorate General for State Hydraulic Works (DSi). Büyükçekmece Barajı ve tesisleri ikmal inşaatı aylık iş durumu. DSi papers, Istanbul; 1985.

27. ISKKi. "Büyükçekmece Barajı son 14 gün içindeki mevcut su hacimleri" https://www.iski.istanbul/web/tr-TR/baraj-doluluk, Last Accessed Date: 03 May 2021.

28. ISKI. "Baraj Doluluk Oranları - Mevcut Su Miktarının Barajlara Göre Dağılımı". http://www.iski.istanbul/web/tr-TR/baraj-doluluk, Last Accessed Date: 11 November 2019.

29. Winter JG, Duthie HC. Epilithic diatoms as indicators of stream total $\mathrm{N}$ and total P concentration. J North Am Benthol Soc 2000; 19(1): 32-49.

30. Hendey NI. A revised check-list of British marine diatoms. J Mar Biolog Assoc UK 1974; 54(2): 277-300.

31. Battarbee RW, Cameron NG, Golding P, Brooks SJ, Switsur R, Harkness $D, M c G o v e r n$ A. Evidence for holocene climate variability from the sediments of a Scottish remote mountain lake. J Quat Sci 2001; 16(4): 339-46.

32. Hustedt F. Heft 10: Bacillariophyta (Diatomeae). Pascher A. editor. Die Süsswasser-Flora Mitteleuropas. Jena, Germany: Verlag von Gustav Fischer; 1930. 466 p.

33. Patrick R, Reimer CW. The diatoms of the United States, Exclusive of Alaska and Hawaii. Philadelphia. Philadelphia, USA:Wiley; 1966. 688 p.

34. Patrick R, Reimer CW. The diatoms of the United States Vol.2, Part 1. Philadelphia, USA: Wiley; 1975.

35. Krammer K, Lange-Bertalot N. Süßwasserflora von Mitteleuropa Bacillariophyceae 3. Teil: Centrales, Fragilariaceae, Eunotiaceae. Stuttgart, Germany: Gustav Fischer Verlag; 1991.

36. Krammer K, Lange-Bertalot N. Süßwasserflora von Mitteleuropa Bacillariophyceae 4. Teil: Achnanthaceae, Kritische Ergänzungen zu Navicula (Lineolatae) und Gomphonema Gesamtliteraturverzeichnis Teil 1-4. Stuttgart, Germany: Gustav Fischer Verlag; 1991.

37. Krammer K, Lange-Bertalot N. Süßwasserflora von Mitteleuropa Bacillariophyceae 1. Teil: Naviculaceae. Berlin, Germany: Gustav Fischer Verlag; 1997. 
38. Krammer K, Lange-Bertalot N. Süßwasserflora von Mitteleuropa Bacillariophyceae 2. Teil: Bacillariaceae, Epithemiaceae, Surirellaceae. Berlin, Germany: Gustav Fischer Verlag; 1997.

39. Siegel S. Nonparametric statistics for the behavioral sciences. New York, USA: McGraw-Hill; 1956.

40. Shannon CE, Weaver W. The mathematical theory of communication. Urbana, USA: The University of Illinois Press; 1949.

41. Clarke KR, Warwick RM. Change in marine communities: An approach to statistical analysis and interpretation ( $2^{\text {nd }}$ edition). Plymouth, England: Primer-E; 2001.

42. Lepš J, Šmilauer P. 2003. Multivariate analysis of ecological data using CANOCO. New York, USA: Cambridge University Press; 2003.

43. McCune B, Mefford MJ. PC-ORD, Multivariate analysis of ecological data (Version 6.22) Oregon, USA: MjM software; 2011.

44. Hammer $\varnothing$, Harper DAT, Ryan PD. PAST: Paleontological statistics software package for education and data analysis. Palaeontol Electron $2001 ; 4(1): 1-9$.

45. Molvær J, Magnusson J, Pedersen A, Rygg B. Vanndirektivet: utarbeidelse av system for marin klassifisering. Framdriftsrapport høsten 2008. TA-2465/2009.

46. Morkoyunlu-Yüce A, Ertan ÖO, Yıldırım, MZ. Epiphytic and epilithic diatoms in dam lakes (Euphrates - Turkey). Yunus Araştırma Bülteni 2015; 3: 45-51.

47. Soylu N, Maraşlıoğlu F, Gönülol A. Epiphytic diatom flora of Liman Lake (Bafra-Samsun). Ekoloji 2011; 20(79): 57-62.

48. Öterler B. Community structure, temporal and spatial changes of epiphytic algae on three different submerged macrophytes in a shallow lake. Pol J Environ Stud 2017; 26(5): 2147-58.

49. Sanal D, Demir, N. Use of the epiphytic diatoms to estimate the ecological status of Lake Mogan. Appl Ecol Environ Res 2018; 16(3): 3529-43.

50. Solak CN, Çetin T, Kaleli A. Distribution of benthic diatom (Phytobenthos) composition in Küçük Menderes River Basin. Turkish Journal of Water Science \& Management 2018; 2(1): 1-35.

51. Akköz C, Güler S. The algal flora of Topçu Lake (Yozgat) I: Epilytic and Epiphytic Algler. S Ü Fen Ed Fak Fen Derg 2004; 23: 7-14.

52. Szabo K, Tihamer KK, Taba G, Acs E. Epiphytic diatoms of the Tisza River, Kisköre Reservoir and some oxbows of the Tisza River after the cyanide and heavy metal pollution in 2000. Acta Bot Croat 2005; 64(1): 1-46.
53. Shaawiat AO, Hassan FM. Qualitative and quantitative study of epiphytic diatoms on two macrophytes in a lotic ecosystem, Iraq. Indian J Ecol 2017; 44(3): 504-15.

54. Round FE. An investigation of two benthic algal communities in Malham Tarn, Yorkshire. J Ecol 1953; 41(1): 174-97.

55. Round FE. Studies on bottom living algae in same lakes of English lake district. Part III. The distribution on the sediments of algal group other than the Bacillariophyceae. J Ecol 1957; 45(2): 649-64.

56. Round FE. Studies on bottom living algae in same lakes of English lake district. Part III. The distribution of Bacillariophyceae on the sediments. J Ecol 1957; 45(2): 343-60.

57. Cox EJ. 1991. What is the basis for using diatoms as monitors of river quality? Whitton BA, Rott E, Fredrich G, editors. Use of algae for monitoring rivers. Innsbruck, Austria: Universitat Innsbruck; 1991.

58. Lange-Bertalot H, Hofmann G, Werum M, Cantonati M. Freshwater benthic diatoms of Central Europe: Over 800 common species used in ecological assessment. Koeltz Botanical Books; 2017.942 p.

59. Koçer MAT, Şen B. The seasonal succession of diatoms in phytoplankton of a soda lake (Lake Hazar, Turkey). Turk J Bot 2012; 36: 738-46.

60. Kelly $M, A c s$ E, Bertrin V, Bennion H, Borics G, Burgess A, Denys L, Ecke F, Kahlert M, Karjalainen SM. et al. Water Framework Directive intercalibration technical report: Lake phytobenthos ecological assessment methods. Publications Office of the European Union; 2014. pp.125,

61. Kindt AC, Small PF. Correlation between temperature, colonization rate, and population density of the diatom Cocconeis placentula in freshwater streams. J Freshw Ecol 2002; 17(3): 441-5.

62. Van Dam H, Mertens A, Sinkeldam J. A coded checklist and ecological indicator values of freshwater diatoms from the Netherlands. Neth J Aquat Ecol 1994; 28(1): 117-33.

63. Cox EJ. Studies on the diatom genus Navicula Bory. VII. The identity and typification of Navicula gregaria Donkin, N. cryptocephala Kütz. and related taxa. Diatom Res 1995; 10(1): 91-111.

64. Reimer CW, Henderson MV, Patrick R. Bibliography, addenda, and corrigenda for The Diatoms of the United States. Proc Acad Nat Sci Philadelphia 2001; 151(1): 129-55.

65. Gümüş F, Gönülol A. Epilithic and epiphytic algae of Taşmanlı Pond (Sinop-Turkey). Karadeniz Fen Bilimleri Dergisi 2017; 7(1): 102-16. 